\title{
SCIENTIFIC AND TECHNOLOGICAL SUBSTANTIATION OF PRODUCTION OF MIXED FODDERS FOR SNAILS
}

\begin{abstract}
The article deals with the issues of modern snail breeding in Ukraine, problems and prospects for their cultivation. The main areas of use of snails are classified. With the proper cultivation of snails, the business is profitable, because meat and slime of snails are expensive, have a lot of useful qualities. The characteristic of the farms for the production of snails in Ukraine and the products of snails - snails, meat, caviar, mucus.

The volumes and methods of growing snails in the world and Ukraine have been analyzed, the tendency of annual increase in livestock and consumption of snails, especially in Europe, is formed, which creates favorable market conditions that guarantee the constant demand for products of activity of snail farms in Ukraine. It was established that in 2018 volumes reached 750 thousand tons. The data of the main countries of producers, importers and consumers of snails in the world are presented. The advantages and disadvantages of the production of snails are determined in comparison with the cultivation of farm animals. The analysis and characterization of feed supplementation for Ahatinka snails and grain-calcium blend used in Ukraine is provided.

Objects of research - Snails Akhaten and snails grape Helix pomatia, fodder for snails. Scientifically substantiated and calculated recipe of full-feed compound for snails using the software complex KormOptimaExpert, which includes grain, protein mineral components and biologically active substances.

The step-by-step scheme of technology of production of mixed fodders for snails is indicated, indicating technological regimes of production, according to which experimental samples of mixed fodder are made. The physical, chemical and microbiological indices of full-fodder mixed fodders for the snails were studied. According to the organoleptic, physical properties and chemical composition, ready-mixed fodder for snails meets the requirements of the State Standard of Ukraine.

The results of the zootechnical evaluation of the developed mixed fodder, according to which it was established that feed for snails during feeding gives a positive zootechnical effect, since the size of the shell at the end of the experiment relates to the commodity, the increase in the mass of snails increased by $13.6 \%$, and the length by $30 \%$ at the coefficient the usefulness of a feed is equal to $1,2 \ldots 1,5$.
\end{abstract}

Key words: snails, snail breeding, growing volumes, recipe, technology, feed.

\section{Introduction}

Today there is a rapid development of technologies, one of the innovations in the agro-industry and feed-processing industry is the cultivation of snails, which does not require significant expenses, the period of cultivation and, with the right approach, is a waste-free technology. Snails are bred artificially. The business of growing snails is profitable. Meat of snails is a nutritious dietary product (the ratio of fats: carbohydrates 70:10:20), as well as strong aphrodisiac, contains protein, essential amino acids: choline - essential for the brain and retinol - necessary for blood vessels, macro-and trace elements (selenium, iron, calcium, zinc, potassium, sodium, magnesium, copper, phosphorus), a large number of fatty acids, without cholesterol and a large amount of vitamins (A, B1, B2B6, B9, B12, E, K, PP) [1-4]. In 100 grams of snail meat contains $90 \mathrm{kcal}$ and has a pleasant taste (Table 1) $[2,5]$.

Snail meat is considered to be a dietary and easily digestible product, therefore it is recommended to all people who have excess weight, metabolic disorders. The snails contain enough calcium, iron, and magnesium, so they help to restore and strengthen the bone and cartilage tissues. In addition to meat, mucus and caviar are snails that are expensive and have a lot of useful qualities [6].

In Ukraine, the most common grape snails are the genus Helix and the snails of the genus Ahatin.

The homeland of Akhatina's snail is East Africa, but after some time, this species of molluscs has often been noticed in the Seychelles, and then throughout Madagascar.
Already in the early 20th century, the snail was discovered in India and in Sri Lanka. And after 10 years the mollusk safely moved to live in Indochina and Malaysia, and then he was brought to Europe [7-9].

Helix pomatia grape snails live in Europe and feel great in Ukraine, but they are the largest gastropods of molluscs that live up to 7 years of age. Snake "commodity" has a weight of 20-25 g and a size of about 5 $\mathrm{cm}$. 1 snail brings up to $1 \mathrm{~kg}$ of litter for a period. From $100 \mathrm{~kg}$ of snails receive up to 2 tons of offspring. In one season, one snail is able to delay up to 40-60 eggs. [10, 11, 16-19].

The main areas of application of snails include: - cooking (restaurants with European cuisine,

Table 1 - The chemical composition and nutrition of meat of snails

\begin{tabular}{||c||c||c||c||c||}
\hline Content & $\begin{array}{c}\text { in } \\
100 \mathrm{~g}\end{array}$ & $\begin{array}{c}\text { The norm } \\
\text { for an } \\
\text { adult per } \\
\text { day, g\% } \\
\text { of the } \\
\text { norm }\end{array}$ & $\begin{array}{c}\text { in } 100 \\
\mathrm{~g} \% \text { of } \\
\text { the } \\
\text { norm }\end{array}$ & $\begin{array}{c}\% \text { of } \\
\text { the } \\
\text { norm } \\
100 \\
\text { kcal }\end{array}$ \\
\hline \hline Calorie content & $90 \mathrm{kKal}$ & $1684 \mathrm{kcal}$ & 5,30 & 5,90 \\
\hline \hline Proteins & 16,1 & 76 & 21,20 & 23,60 \\
\hline \hline Fat & 1,4 & 60 & 2,30 & 2,60 \\
\hline \hline Carbohydrates & 2,0 & 211 & 0,90 & 1,00 \\
\hline \hline
\end{tabular}


elite supermarkets, frozen semi-finished products). Terrestrial mollusks are served in prestigious restaurants in Ukraine and the world, and semi-finished products are sold in supermarkets of large cities, all of which is imported from France and other countries of Western Europe;

- cosmetology "sclotherapy" (snails in cosmetology play an important role, since their mucus possesses a rich composition for useful substances);

- jewelery and decor (snail shells can be used as souvenirs and jewelry);

- livestock breeding (in poultry farming, shellfish snails and minced meat for feeding farm birds, as well as non-conditioned snails) $[1,3,10,12]$.

The purpose of the work is development of recipes and technologies of production of mixed fodders and additive for snails (genus Akhanin and Helix), estimation of their zootechnical and economic efficiency.

To achieve this goal it was necessary to solve the following tasks:

- to analyze the volumes of the production of snails in the world and in Ukraine;

- to identify the advantages and disadvantages of snails in comparison with the cultivation of farm animals;

- analyze the market and characteristics of feed additives and fodder for snails;

- calculate the recipe for full-fodder feed for snails;

- to study physical, chemical and microbiological indicators of full-fodder feed;

- To conduct a zootechnical evaluation of the developed feed.

Objects of research - Snails Akhaten and snails grape Helix pomatia, fodder for snails.

In the work, when determining the quality of feed raw materials and finished feed additives, standard methods of research were used. The appearance and size of the snails were determined visually and with the help of a caliper. Mass of snails by weighing on technical scales over a period of time.

\section{Analysis of literary data and problem statement}

Today in the world 420-450 thousand tons of molluscs are sold for about \$ 12 billion. Of these: 15\% are grown on special farms, while others are collected in natural conditions. In the structure of global production of snails, the leaders are Morocco - 47\%, Spain - 20\%, Indonesia - $18 \%$, followed by China - 9\% and Romania $6 \%[10,20]$.

The leader among buyers of snails is China with a share of more than $40 \%$ of world imports. Followed by European countries, famous for their exotic cuisine France $(23.12 \%)$, Italy $(10.46 \%)$, Belgium $(5.76 \%)$, Greece $(4.16 \%)$ and others $(13.62 \%)$ [ 10,20$]$

The world market of snails in 2018 amounted to 750 thousand tons, snail meat - more than 110 thousand tons, and demand is met by a maximum of $70 \%$. In 2017 , the world's production of snails was 650 thousand, in Ukraine - 415 tons (Fig. 1). In 2018, for the first 3 months. there is a decline - production volume amounted to 60.5 tons, which is explained by the purchase of young snail farmers. However, despite the fact that Ukraine consumes very little snail meat (10-12 tons per year), Ukraine in recent years has considerably increased exports of snails to France, Spain, Poland, Germany, Belgium, and Britain [10-14, 20].

Import of snails increased significantly in Ukraine. In 2015, they were imported for 0,2 thousand dollars $(0,4 \mathrm{~kg})$, and already in 2016- 4,8 thousand dollars $(977,9 \mathrm{~kg})$. In 2016, just like a year earlier, China became the main supplier of mollusks to Ukraine. The second place is France. It is noteworthy that in 2015 Russia blocked the top three importers of molluscs in Ukraine - \$ 861.2 th. (593 tons). Already in 2016, deliveries from this country decreased by almost 8.5 times [10-14, 20]

The main advantages of snail breeding include: meat contains a minimum of cholesterol $-48 \mathrm{mg} / \mathrm{kg}$ (pork - $83 \mathrm{mg} / \mathrm{kg}$, beef - $126 \mathrm{mg} / \mathrm{kg}$ ), which helps to protect the heart and human circulatory system; strong aphrodisiac (dominated by chocolate and strawberries) used to enhance feelings; snails emit 80 times less methane than cows; To get 200 calories, a person consuming meat snails, eat the least fat and most proteins in comparison with other meat; ease of breeding and care, do not hurt $[2,4,15]$.

There are three ways of breeding snails [21-24]:

1. extensive - involves the cultivation of molluscs in natural conditions, involves growing completely in the open area. The advantage of this method is a low budget, a drawback is the long term of cultivation. Cultivation under natural conditions is suitable for private arboretum, botanical garden or park. It is in these conditions that it is possible to exclude the main enemies of mollusks: rodents, birds, wild boars. Existing in a closed territory the snails do not crack.

2. The intensive method is more suitable for breeding on an industrial scale, provides for breeding in a closed room of the greenhouse type. In this case, it is necessary to create an optimal microclimate for molluscs (constant maintenance of the required temperature and humidity) and intensive feeding. With this method, they grow and mature much faster (in about a year and a half). Advantages of the intensive method: obtaining a high number of individuals and their eggs, which are called "white caviar". Cons: high initial costs and high complexity.

3. Semi-intensive breeding of snails in open pits, where natural shading and moisturizing are organized, as

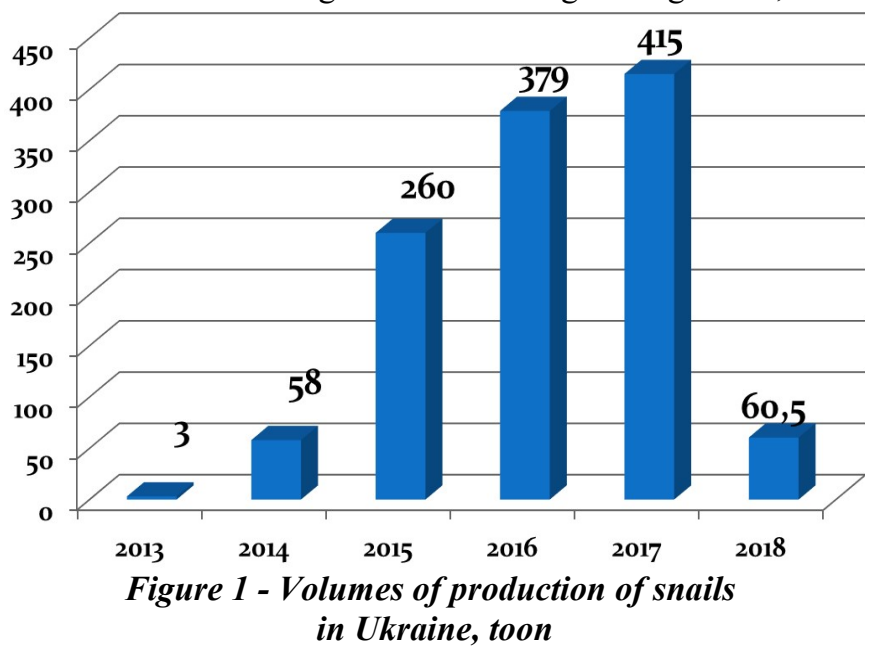




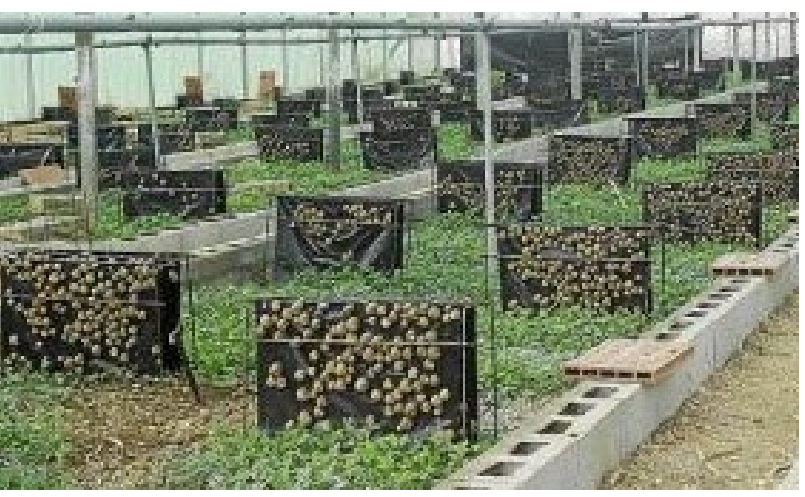

Figure 2 - View of the farm for snails

well as a good organization of feeding, with the addition of moderate amounts of feed. Thus, snails grow and ripen in 2-2,5 years, based on the conditions of cultivation and retention. The benefits of a semi-intensive method: low initial costs, the possibility of growing on a small area, rather low complexity. Disadvantages of the method: relatively slow growth and development of individuals (slower than in intensive mode) [26, 27, 33]. This technique is quite universal - suitable for breeding both in industrial production and in private subsidiary farms.

In the case of growing molluscs by semiintensive method in a private auxiliary farm, it is possible to save a lot on their feeding. Dandelion, nettles, burdock, eggplant, horse sorrel and other wild plants will fit the diet of the individuals. You can use food waste, processed fruits and vegetables, leaves. Thus, the semiintensive method is most suitable for domestic breeding the cost of food will be virtually eliminated.

With the maintenance of snails, provision is made for feeding with natural forages, feed additives and a combined method. A special need for a diet should be the presence of calcium to strengthen their shell [21-29].

The most popular method of breeding snails is the farm. The first gluten farm in Ukraine appeared in Transcarpathia in 2010 [18]. Today in Ukraine there are 15 gilly farms, $90 \%$ of which is exported. Among the largest include: "Snail Elf" (Kyiv region); Eco Ravlyk (Vinnytsia region); "Western Snail", "Organic Escargo"; Ponebel (Lviv region); "Restaurant" (Khmelnytsky region); "Farm M. Demian", "Pokutskiy snail" (Ivano-
Frankivsk region); "Aulika" (Zhytomyr region); "FGRavlyk-2016" and "USH (Ukrainian Snail Holding)" (Poltava region); "Zdravlik" (Dnipropetrovsk region); Aunt sophie snails (Kherson region); "Squirrel House" (Kharkiv region); Family Snail Farm (Odesa region) [10$14,20,26,27,33]$. The Ravlyk Farm is a farm that aims to develop a culture of snail consumption in Ukraine, as well as the integration of quality tools for growing molluscs in Ukrainian agriculture (Table 2).

Breeding of snails in artificial, "greenhouse" conditions is also a guarantee that the meat that is sold will be free from various contaminations - heavy metals, pesticides and others. Propagating snails are good. Only they need space. Normal conditions for their lives are created when 40-50 snails (that is, about a kilogram) live on 1 square meter.

In the Zhytomyr region and throughout the whole of Ukraine, the grape snail is spread. People who decide to do this business must imagine the life cycle of this snail, taking into account the factors of the environment: temperature, humidity, thermal regime. For example, our snail does not like the dry continental climate. However, it does not fit and excessive moisture. Usually the snail lives up to seven years, but in the conditions of our climate, it becomes sexually mature and commercial only for the third year. That is, it reaches those sizes that allow it to be used as a food product. So, in terms of outdoor parking, one should expect that the return will not be earlier than 2 years. The snail in the natural environment grows more slowly than a rabbit or a cow.

Today in the forage market of Ukraine there are such types of additive for snails as: ahatinka, graincalcium mixture for ahatian, dried gammarus and mixed feed, which is usually imported.

Ahatinka is a universal protein-calcium feed additive for snails [30]. Advantages: Suitable for all types of Achatina, arachatin, lymph coli; accelerates the growth and for mation of a healthy strong shell; it has an attractive taste and smell for snails; Suitable for snails of all ages; Recommended for daily use.

Composition: shells of mollusks, shells of raw chicken and quail eggs, sepia (cuttlefish), chalk, groats (oats, buckwheat, corn, wheat), gammarus, fish meal, meat and bone meal, tricalcium phosphate, vitamin and

Table 2 - Pricing policy for snails in Ukraine

\begin{tabular}{|c|c|c|c|c|c|}
\hline \multirow[b]{2}{*}{ № } & \multirow[b]{2}{*}{ Name products } & \multicolumn{4}{|c|}{ Price, UAH } \\
\hline & & «Eco snail» & $\begin{array}{c}\text { «Ukrainian } \\
\text { Snail Holding» }\end{array}$ & $\begin{array}{l}\text { «Organic } \\
\text { Escargo» }\end{array}$ & «West snail» \\
\hline 1 & Live snails, $1 \mathrm{~kg}$ & & $240-320$ & 896 & 200 \\
\hline 2 & Motherwort & & $260-370$ & $310-372$ & \\
\hline 3 & Snail fillet in marinade, $1 \mathrm{~kg}$ & 1000 & $1180-1580$ & & 1300 \\
\hline 4 & $\begin{array}{l}\text { Ready-made semi-finished stuffed in shell with } \\
\text { different sauces, } 1 \mathrm{~kg}\end{array}$ & 950 & $1000-1500$ & 1200 & 980 \\
\hline 5 & Snail Lux (maxim), $1 \mathrm{~kg}$ & 950 & & & \\
\hline 6 & "Snail in a plum sauce", a bank of 400 grams & 170 & & & 200 \\
\hline 7 & Snail fillet, $1 \mathrm{~kg}$ & 1300 & & & 1300 \\
\hline 8 & Caviar of snails, 100 grams & 3000 & & 3990 & 2800 \\
\hline 9 & Slime of snails, $1 \mathrm{~kg}$ & & & 4900 & \\
\hline
\end{tabular}


Table 3 - Recipes for fodders for snails and their nutritional value,\%

\begin{tabular}{|c|c|c|c|}
\hline Components & $\begin{array}{c}\text { MF } \\
\text { Ahatinka }\end{array}$ & $\begin{array}{c}\text { MF } \\
\text { Bulgaria }\end{array}$ & $\begin{array}{c}\text { Experimental } \\
\text { sample MF }\end{array}$ \\
\hline Wheat & 69 & 10 & 20 \\
\hline Barley without films & - & - & 20 \\
\hline Maize & - & 30 & 15 \\
\hline Wheat bran & $\overline{5}$ & 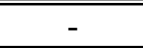 & 3 \\
\hline Soybean meal & 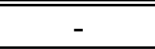 & 21,5 & - \\
\hline Fish meal & 10 & - & 7 \\
\hline Meat and bone meal & 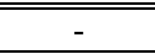 & - & 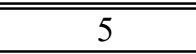 \\
\hline "Monochlorohydratlizine 98 & - & 0,1 & - \\
\hline Salt cooked & 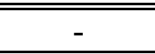 & 0,4 & - \\
\hline Tricalcium phosphate & 12 & $\overline{5}$ & 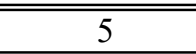 \\
\hline Chalk feed & - & 30 & 24 \\
\hline Eggshell & 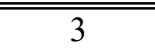 & - & - \\
\hline Premix & 1 & 3 & 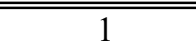 \\
\hline $\begin{array}{c}\text { The price of mixed feed with } \\
\text { VAT, UAH / ton }\end{array}$ & "14219,0 & 1010766,0 & 99526,0 \\
\hline \multicolumn{4}{|c|}{ Indicators of nutrition } \\
\hline Raw protein & 15,56 & 13,68 & 14,58 \\
\hline Crude fiber & 2,34 & 2,38 & $1,1,57$ \\
\hline Lizin & 0,75 & 0,79 & 0,66 \\
\hline Methionine & 0,32 & 0,20 & 0,26 \\
\hline Methionine + Cystine & 0,58 & 0,43 & 0,46 \\
\hline Calcium & 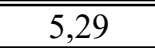 & 11,59 & 10,19 \\
\hline Phosphorus & 2,22 & $1,1,00$ & $1,1,30$ \\
\hline Phosphorus is digestible & 1,68 & 0,65 & 0,96 \\
\hline Sodium & 0,17 & $0,0,67$ & 0,40 \\
\hline
\end{tabular}

mineral complex. Average price - $28 \mathrm{UAH} / 100 \mathrm{~g}$.

Forage for AHATIN grain-calcium mixture of ground snails $100 \mathrm{~g}$ Zelena Zoo - the main feed for land snails: the best source of calcium for land snails Ahatin, Arachatin, Limicolaria and other animals. It is best fed with snails and in dry form from a bowl, and mixed with juicy food [31]. Ingredients: $50 \%$ of grain (oat flakes, rice, buckwheat, millet, mix for exotic birds, vitamin and mineral complex), 50\% calcium (sepia - cuttlefish shell, natural forage chalk, raccoon, egg shell). Average price $13 \mathrm{UAH} / 100 \mathrm{~g}$.

\section{Research results}

Based on the literary search, taking into account the needs and taste preferences of snails, and analysis of the existing additive for snails, we have calculated and optimized the recipe for compound feeds for snails for the software complex KormOptim Expert (Voronezh). Optimization was carried out in terms of the nutritional value of feed (the content of exchange energy, crude protein, crude fiber, amino acids, calcium, phosphorus, sodium) and its value.

In the calculation, a comparison of the calculated recipe with recipes for feedstuffs for Achatin and feed for the snails produced in Bulgaria was carried out. The recipes of feed and their nutritional value are given in Table 3.

It is established that the feed on the developed recipe is not inferior to the fodder that are offered today for the cultivation of snails, and at a cost is cheaper.

According to the calculated recipe, feed was obtained in accordance with the phased technological scheme presented in Fig. 4. Technological process of production of mixed fodder was carried out in accordance with the "Rules of organization and maintenance of the technological process of production of fodder products" (Kiev, 1998).

All raw materials used for the production of mixed fodders for snails come in a certain size in a paved species in bags and should be characterized by the passage of the sieve № 20 (a lattice with a diameter of holes $\varnothing 2 \mathrm{~mm}$ ) or SD № 1,6 (wire mesh with a cell size of 1 , $6 \times 1.6 \mathrm{~mm}$ ) not less than $95 \%$.

The raw materials are alternately fed to a dipping unit in a folding cabinet, which has a metal mesh with $50 \times 50 \mathrm{~mm}$ holes, to remove random impurities.

If necessary, the raw material must undergo preliminary granulometric preparation. The raw material, which does not meet the requirements for grain size, is crushed in a hammer crusher, in which a sieve shell with a diameter of holes $\varnothing 3 \mathrm{~mm}$ is installed. The grinding products are sent to a sifting machine, which installs a sieve - a cloth of a lattice № 20 with a diameter of holes $\varnothing 2 \mathrm{~mm}$. Orient sieve № 20 with diameter of holes $\varnothing 2$ $\mathrm{mm}$ is sent for repeated grinding in the same hammer crusher. The passage of the sieve № 20 with the diameter of the holes $\varnothing 2 \mathrm{~mm}$ - is sent to an electromagnetic

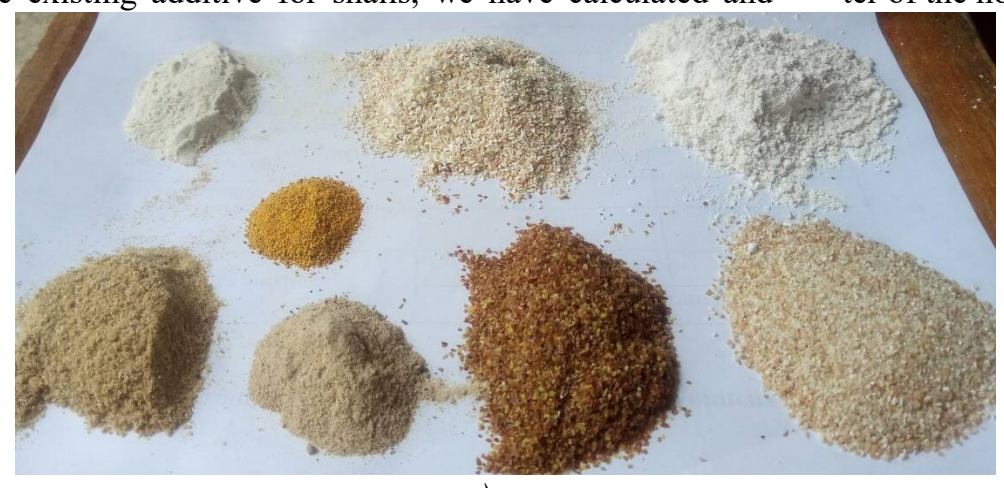

a)

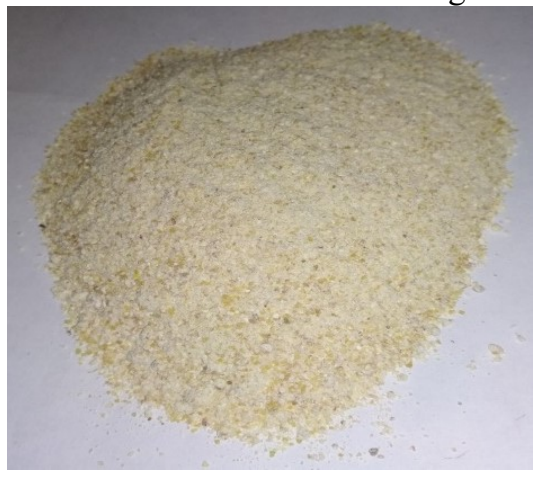

b)

Figure 3 - Components (a) and ready-mixed fodder (b) for snails 


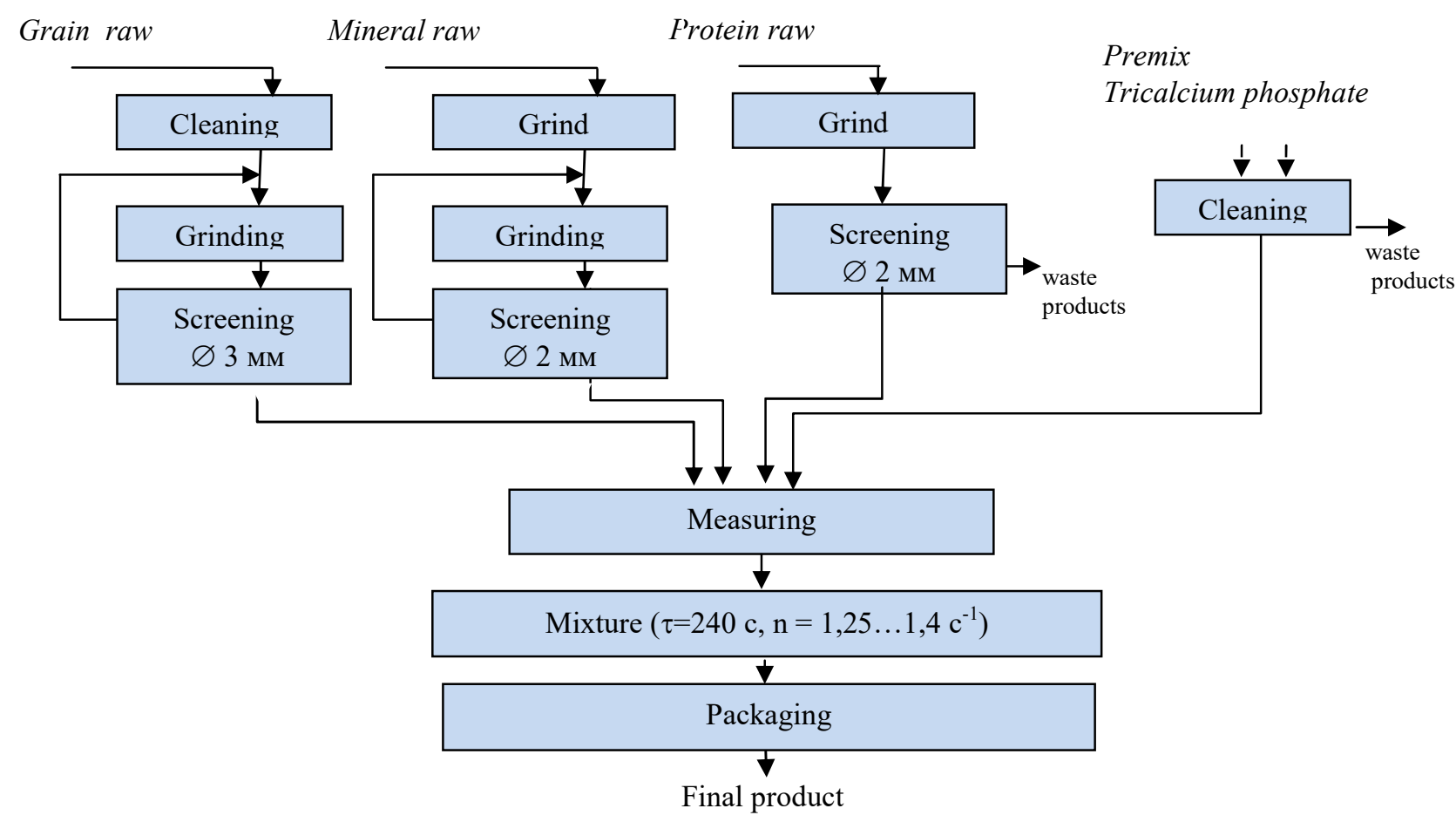

Figure 4 - A phased scheme for the production of mixed fodders for snails.

separator for the separation of metal-magnetic impurities, and then into the suppository bunkers.

Prepared components (Fig. 3, a) are dosed according to the recipe on a weight dispenser. The suspended components are sent to the mixer. The main mixing of the doped components is carried out in a periodic mixer with a blasting mixing device for $240 \mathrm{~s}$ at a rotation frequency of the mixing device operating unit $\mathrm{n}=1,25 \ldots 1,4 \mathrm{c}^{-1}$. Ready mixed fodder (Fig. 3, b) for snails is packed in bags of $50 \mathrm{~kg}$ or a small container of $100 \mathrm{~g}$ cans.

Painted fodder was studied by definition of physical, chemical and microbiological quality indices.

Organoleptic characteristics of feed for snails: appearance - a dry homogeneous mixture without solid lumps with the color inherent in the combined color of the mixed-recipe components (gray) (Fig. 3, b). The smell is inherent in the combined odor of the mixedrecipe components (slightly pronounced fish).

Physical indicators of feed for snails: the mass fraction of moisture $-10,5 \%$, volume mass $-720 \mathrm{~g} / 1$, the natural slope angle - 48grad., The brightness $-6,3 \mathrm{~cm} / \mathrm{s}$, the size $-0,56 \mathrm{~mm}$.

Analysis of the physical properties of the components of the feed additive indicates that all the components refer to heavy-duty raw materials, since the angle of the natural slope is more than 40 deg. These properties must be taken into account when choosing technological regimes for the preparation of raw materials for the production of feed (the gradient angle of gravity, bottom bunkers, the height of the embankment in bunkers, etc.).

According to the organoleptic, physical properties and chemical composition, ready-mixed fodder for snails meets the requirements of the State Standard of Ukraine.

The microbiota is determined in order to find out what microorganisms present in the feed. In the presence of Salmonella and Intestinal Sperm Bacteria (ISB), feed may be dangerous to animal feeding. The microbiological parameters of the mixed fodder were evaluated by the determination of the number of bacteria, mold fungi, Salmonella and BGKP. Fodder was stored in unregulated conditions for 1 month. The results are presented in Table 4.

It has been established that according to the quality indices the experimental sample of mixed fodders for snails meets sanitary requirements, since the amount of CFU is less than 500 in $1 \mathrm{~g}$. In the developed experimental sample, the number of colonies is higher than in the mixed fodder of the Bulgarian production due to the presence of animal feed (meat-bone meal).
Table 4 - Microbiological indicators of feed for snails

\begin{tabular}{|c|c|c|c|c|c|c|c|}
\hline \multirow{2}{*}{$\begin{array}{c}\text { Sample } \\
\text { mixed } \\
\text { fodder (MF) }\end{array}$} & \multicolumn{3}{|c|}{ Bacteria } & \multicolumn{2}{|c|}{$\begin{array}{l}\text { Mushroom } \\
\text { mushrooms }\end{array}$} & \multirow{2}{*}{ 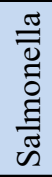 } & \multirow{2}{*}{$\stackrel{2}{2}$} \\
\hline & \multicolumn{2}{|c|}{$\begin{array}{c}\text { Number of } \\
\text { colonies in a cup }\end{array}$} & $\begin{array}{c}\text { nMAFAnM } \\
\text { CFU / g }\end{array}$ & $\begin{array}{c}\text { Dissolvi } \\
\text { ng }\end{array}$ & $\mathrm{SFU} / \mathrm{g}$ & & \\
\hline MF Ahatinka & \multirow{3}{*}{$\begin{array}{c}\text { Norm } \\
\text { no } \\
\text { more } \\
\text { than } \\
500\end{array}$} & 205 & 2050 & $1: 10$ & \multirow{3}{*}{$\begin{array}{l}\text { Mushroom } \\
\text { s of the } \\
\text { family } \\
\text { Mucorales }\end{array}$} & \multirow{3}{*}{ 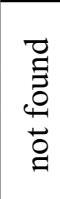 } & \multirow{3}{*}{ 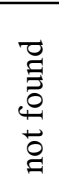 } \\
\hline MF Bulgaria & & 99 & 3900 & $1: 100$ & & & \\
\hline $\begin{array}{l}\text { Experimental } \\
\text { sample MF }\end{array}$ & & 107 & 2700 & $1: 100$ & & & \\
\hline
\end{tabular}

The zootechnical evaluation is the final result of determining the effective action of fodder [34]. The zootechnical evaluation of the feed was carried out using 3 groups of snails: control and 2 experiments on 7 units in each group. Conditions for keeping snails: temperature $+18 \ldots$ 


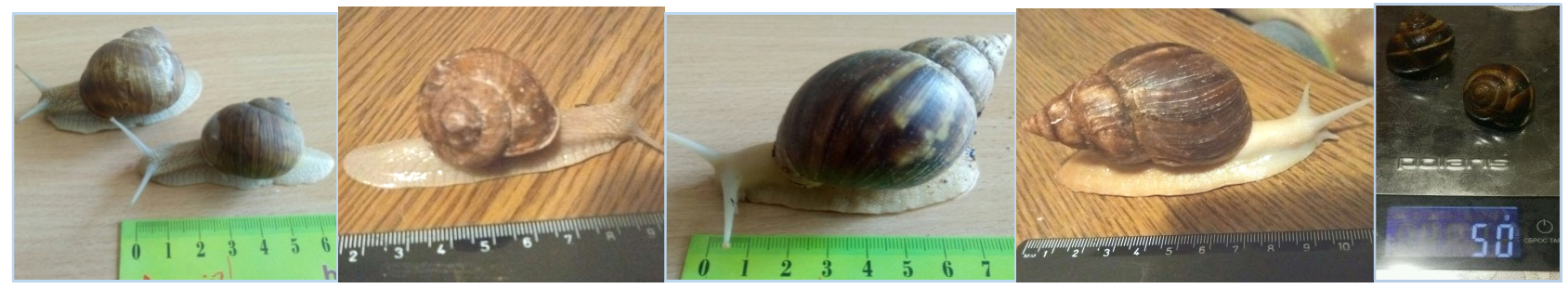

Figure 5 - Determining the length of the leg and the weight of the snails

Table 5 - Dynamics of live weight and growth of legs of snails during feeding of mixed fodder

\begin{tabular}{|c|c|c|c|c|c|c|c|}
\hline \multirow{3}{*}{ Month } & \multirow{2}{*}{\multicolumn{2}{|c|}{ Control }} & \multicolumn{5}{|c|}{ Testing Groups snails } \\
\hline & & & \multicolumn{3}{|c|}{ Helix pomatia } & \multicolumn{2}{|c|}{ Akhaten } \\
\hline & $\mathrm{m}, \Gamma$ & $1, \mathrm{MM}$ & $\mathrm{m}, \Gamma$ & $1, \mathrm{MM}$ & b, мM & $\mathrm{m}, \Gamma$ & 1, MM \\
\hline 1 & 92,8 & 42 & 93,4 & 47 & 18 & 144,7 & 50 \\
\hline 2 & 95,0 & - & 96,4 & - & - & 148,33 & - \\
\hline 3 & 97,8 & 48 & 99,8 & 55 & 26 & 154,82 & 62 \\
\hline 4 & 99,2 & - & 101,0 & - & - & 157,76 & - \\
\hline 5 & 101,4 & 56 & 103,1 & 62 & 35 & 162,3 & 87 \\
\hline 6 & 102,5 & - & 104,6 & - & - & 166,8 & - \\
\hline 7 & 104,1 & 63 & 105,9 & 69 & 48 & 172,3 & 91 \\
\hline 8 & 105,8 & - & 107,0 & - & - & 174,7 & - \\
\hline
\end{tabular}

length by $30 \%$ at the feed conversion ratio (FCR) $1.2 \ldots 1.5$

\section{Conclusions}

1. The growth of consumption of snails, especially in Europe, forms favorable market conditions that ensure a guarantee of constant demand for products of activity of snail farms in Ukraine.

2. Growing of snails is a waste-free production with a closed cycle, which allows to get a commodity snail, meat, white caviar, offspring. Creation of snail farms allows to expand the domestic assortment of high biological value food products, as well as feed products.

3. Growing of snails is one of the directions of the solution of protein deficiency in the food and feed industry and the rational use of land resources.

4. Scientifically grounded and developed

$30^{\circ} \mathrm{C}$, relative humidity $75 \ldots 90 \%$, world day $9 \ldots 11 \mathrm{~h}$.

The control group fed the main diet (OR): cucumbers, lettuce, apples, carrots in the same amount. Experimental groups received the main diet and $2 \mathrm{~g}$ of feed per day. Fodder was fed at evening and night time, pre-creating conditions for spraying "fog" with the help of a humidifier.

The assessment was conducted on the following indicators: growth of live weight $(\mathrm{m}, \mathrm{g})$; the length of the leg of the snails $(1, \mathrm{~mm})$ and the width of the snail $(b$, $\mathrm{mm})$. The results of averaged research are shown in Table. 5 and Fig. 5

Fodder for snails during feeding gives a positive zootechnical effect, since the size of the shell at the end of the experiment refers to the commodity, the increase in the mass of snails increased by $13.6 \%$, and the

\section{REFERENCES} recipes of mixed fodders for snails with feed conversion ratio $1,2 \ldots 1,5$, which allow more rational use of nontraditional types of raw materials.

5. According to the organoleptic, physical properties and chemical composition, the finished product meets the requirements of the State Standard of Ukraine. According to microbiological indicators of quality, feed meets the requirements, since the amount of CFU is less than 500 per $1 \mathrm{~g}$.

6. Fodder for snails during feeding gives a positive zootechnical effect, since the size of the shell at the end of the experiment refers to the commodity (about $50 \mathrm{~mm}$ ), the increase in the mass of snails increased by $13.6 \%$, and the length by $30 \%$

7. The Ravlyk Farm can be considered as an object of tourism business

1. Ahmadu J., Ojogho O. Economics of snail production in Edo State, Nigeria. International Journal of Agriculture Sciences 4.5, 2012. pp. 233-237.

2. Mandal. L. Snail power - a protein source for poultry // Feed mix, 2003. - Vol. 11. - \# 4. - P. 25

3. Cobbinah JR., et al. "Snail Farming: Production, processing and marketing”. Agromisia Foundation, Wageningen. First Edition, 2008. pp. 78-82.

4. Danilova I.S. The Content of Fatty Acids in Meat of Different Kinds of Snails // The Bulletin of the Poltava State Agrarian Academy, 2018. - No. 4. - P. 168-173. DOI 10.31210/visnyk2018.04.26.

5. Burlaka V.A./ The content of protein and vitamins in meat in the cultivation of snail // Fodder and fodder production, 2008. - Vip. 63. - pp. 247-251.

6. Farm Farm. Caviar snail. [Electronic resource]. Access point: https://zdravlyk.prom.ua/p690901582-ikra-ravlika100.html

7. Vogler R.E., Beltramino A.A., Sede M.M., Gutiérrez Gregoric D.E., Núñez V., Rumi A. The giant Africansnail, Achatina fulica (Gastropoda: Achatinidae): Using bioclimatic models to identify South American areas susceptible to invasion. American Malacological Bulletin, 2013. - .31(1):39-50.

8. Ogbu, C.C., Ani, A.O., Emeh, M., 2014. Feed preferences and feeding behaviour of two species of african giant land snails preferencias y comportamiento alimentario de dos especies de caracoles terrestres gigantes africanos // Recibido: 3-4-13. Aceptado: 17-3-14. Arch. Zootec. 63 (242): pp. 337-347.

9. Hayes K.A., Joshi R. C., Thiengo S.C., Cowie R.H. 2008. Out of South America: multiple origins of non-native apple snails in Asia. Diversity Distrib., 14 (4): pp. 701-712.

10. Analysis of the market of edible frogs and snails of Ukraine. 2018 year Pro-Consulting Company, 2018. - 44 p

11. Uphill farm - quick profit! [Electronic resource]. Access point: https://zdravlyk.prom.ua/a328292-ulitochnaya-ferma-bystraya.html. 
12. Vinnychuk Yu. What is known about the export of snails from Ukraine. [Electronic resource]. Access point: https://biz.censor.net.ua/resonance/3019292/chto_izvestno_ob_eksporte_ulitok_iz_ukrainy.

13. "Its niche": why Ukrainians breed snails, although they can not sell them. Electronic resource. [Access Point]: https://agroonline.com.ua/en/public/blog/40235/details.

14. As the snails overcame fat // Ukraina Moloda, 2017. Issue number 125. October $19 . \quad-\quad$ P. 9. http://www.umoloda.kiev.ua/number/3226/159/116867/

15. Xiangqian X., Chen C., Yeast A. Alternative protein resources in China. [Електронний ресурс]. Точка доступу: https://www.allaboutfeed.net/New-Proteins/Articles/2018/10/Alternative-protein-resources-in-China-345433E.

16. Halwart M., 2006. Fish as biological control agents of golden apple snails in Philippine rice fields. In: Joshi, R. C.; Sebastian, L. S. (Eds.), Global advances in ecology and management of golden apple snails: pp. 363-374.

17. Joshi R.C., Cowie R.H., Sebastian L.S., 2017. Biology and management of invasive apple snails. Philippine Rice Res. Institute (PhilRice), Maligaya, Science City of Muñoz, Nueva Ecija 3119.

18. Phonekhampheng O., Hung L.T., Lindberg, J.E., 2009. Ensiling of Golden Apple snails (Pomacea canaliculata) and growth performance of African catfish (Clarias gariepinus) fingerlings fed diets with raw and ensiled Golden Apple snails as protein source. Livest. Res. Rural Dev., p. 21 (2).

19. Etchu K., et al. "Comparative performance of three edible snail species using intensive cage housing system in Cameroon". Bulletin of Animal Health and Production in Africa 56.4 (2008): pp. 345-352.

20. Imperfect payrolls that give a quick return: to create snail farms in Ukraine. [Electronic resource]. Access point: https://proconsulting.ua/ua/pressroom/netoroplivye-podopechnye-prinosyashie-bystruyu-pribyl-o-sozdanii-v-ukraine-ulitochnoj-fermy.

21. Mogbo T.C., et al. "Growth performance of snails (Achatina fulucia) fed with three different feed materials". American Journal of Biology and Life Sciences 2.4 (2014): pp. 96-99.

22. Nyameasem J.K., Borketey-La E.B. Effect of formulated diets on growth and reproductive performance of the west african giant snail (Achatina achatina) // ARPN Journal of Agricultural and Biological Science. VOL. 9, NO. 1, JANUARY 2014. P. 1-6.

23. Okon B., Ibom L.A., Ettah H.E., Ukpuho I.E. Effects of genotype, dietary protein and energy on the reproductive and growth traits of parents and f1 hatchlings of Achatina achatina (L) snails in Nigeria // International Journal of Applied Science and Technology Vol. 2 No. 1; January 2012. - pp. 179-185.

24. Egonmwan R., 2007. Recent Advances in the Biology of Giant African Land Snails (On-line pdf). Federal University of Agriculture, Abeokuta. Accessed March 05, P. 201.

25. Mayaki O.M., Ozumba A.U., Aderele A.A., DaramolaA.O. Effect of Sources of Fibre on Performance of Growing Snail // Nigerian Food Journal. Volume 31, Issue 1, 2013, P. 28-32.

26. Burlaka V.A., Shevchuk V.F., Belyaev S.M. Cultivation of Helix pomatia in the conditions of the Polissya of Ukraine // Ecologicalfunctional and faunistic aspects of researches of molluscs, their role in bioindicating the state of the environment / Zbir.nak.pr. Zhytomyr "Volyn". - 2004. - P. 15-17.

27. Freeman E.T. "Farmer Level Technical-note, improved snail farming" (2013): P. 27.

28. Owoseni DO and Adetunji AA. "The effect of feeds on weight of African giant snails (Archachatina marginata)". World Journal of Animal Science Research 1.1 (2013): 1-7.

29. Ani A.O., et al. "Growth performances of African giant land snail (Achatina achatina) fed varying dietary protein and energy levels". ARPN Journal of Agriculture and Biological Science 8.2 (2013): pp. 184-190.

30. Ahatinka is a universal protein-calcium feed for snails. [Electronic resource]. Access point: https://faunamarket.com/products/7661.

31. Fodder for AHATIN grain-calcseum of ground snails $100 \mathrm{~g}$ Zelena Zoo. [Electronic resource]. Access point: http://aquamaniya.com.ua/zootovar/terrarium/korm-zerno-kaltsesmes-dlya-ulitok-ahatin.

32. Amubode, F. O. ; Ogogo, A. U., 1995. Performance of snails (Archachatina marginata) fed varying levels of calorie-protein supplementary diets. Nigerian J. Forestry, 24/25: pp. 36-43.

33. Ravlikov Farm in the village of Kopachyntsi. [Electronic resource]. Access point: https://www.ravlyk.if.ua.

34. Gordeeva E.A., Loginova M.N. Observation of the growth and development of ground snails, Achatina sp. // Young scientist. - 2016 - №3. - P. $165-170$.

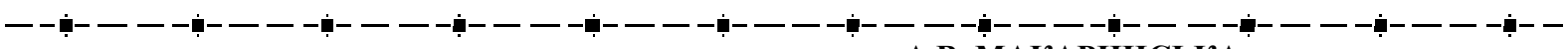

А.В. МАКАРИНСЬКА, канд. техн. наук, доцент

Л.М. ЯРМАК, магістр, О.М. ПІДДУБНЯК, студент ф-ту ТЗіЗБ Одеська національна академія харчових технологій, Одеса

\section{НАУКОВО-ТЕХНОЛОГІЧНЕ ОБГРУНТУВАННЯ ВИРОБНИЦТВА КОМБІКОРМІВ ДЛЯ РАВЛИКІВ}

\section{Анотація}

В статті розглянуті питання сучасного равликівництва в Украӥні, проблеми та перспективи їх вирощування. Класифіковані основні сфери використання равликів. При правильному вирощуванні равликів бізнес є прибутковим, адже м'ясо та слиз равликів дорогі, мають велику кількість корисних якостей. Надано характеристику ферм $з$ вирощування равликів в Україні та продуктам равликівнищтва - равлики, м'ясо, ікра, слиз.

Проаналізовані об'єми та способи вирощування равликів у світі та Україні, встановлено тенденцію щчорічного збільшення поголів'я та обсягів споживання равликів, особливо в Свропі, щьо формує сприятливі ринкові умови, які забезпечують гарантію постійного попиту на продукиію діяльності равликових фермерських господарств в Україні. Встановлено, що у 2018 роиі об'єми сягли 750 тис.т. Наведено дані основних країн виробників, імпортерів та споживачів равликів у світі. Визначені переваги та недоліки вирощування равликів у порівнянні з вирощуванням сільськогосподарських тварин. Проведено аналіз та надано характеристику кормових підкормок для равликів Ахатинка та зерно-кальиієвої суміші, які використовують в Украйні.

Об'єкти досліджень - равлики Ахатини та равлики виноградні Helix ротатіа, комбікорм для равликів.

Науково обгрунтовано та розраховано рецепт повнораціонного комбікорму для равликів за допомогою програмного комплексу КормОптимаЕксперт, до складу якого входять зернові, білкові мінеральні компоненти та біологічно активні речовини. Наведено поетапну схему технологї виробництва комбікормів для равликів, з вказівкою технологічних режимів виробництва, згідно з якою виготовлені дослідні зразки комбікорму. Вивчені фізичні, хімічні $i$ мікробіологічні показники повнораціонного комбікорму для равликів. За органолептичними, фізичними властивостями та хімічним складом готовий комбікорм для равликів відповідає вимогам ДСТУ.

Представлені результати зоотехнічної очінку розробленого комбікорму, згідно яких встановлено, що комбікорм для равликів при згодовуванні дає позитивний зоотехнічний ефект, оскільки ракушка за розмірами на кінець 
експерименту відноситься до товарної, приріст маси равликів збільшився на 13,6\%, а довжина на 30 \% при рівні конверсії комбікорму рівному 1,2...1,5.

Ключові слова: равлики, равликівництво, об 'єми вирощування, рещепт, технологія, комбікорм.

\section{ЛITЕРАТУР}

1. Ahmadu J., Ojogho O. Economics of snail production in Edo State, Nigeria. International Journal of Agriculture Sciences 4.5 (2012): pp. 233-237.

2. Mandal L. Snail power - a protein source for poultry // Feed mix, 2003. - Vol. 11. - \# 4. - P. 25.

3. Cobbinah J.R., et al. "Snail Farming: Production, processing and marketing”. Agromisia Foundation, Wageningen. First Edition (2008): pp. 78-82.

4. Данілова І.С. Вміст жирних кислот у м'ясі різних видів равликів // Вісник Полтавської державної аграрної академї, 2018. - № 4. - C. 168-173. DOI 10.31210/visnyk2018.04.26.

5. Бурлака В.А. Вміст протеїну та ВМ в м'ясі при вирощуванні слимака // Корми і кормовиробничтво, 2008. - Вип. 63. - С. 247-251.

6. Фермерське господарство Здравлик. Ікра равлика. [Електронний ресурс]. Точка доступу: https://zdravlyk.prom.ua/p690901582ikra-ravlika100.html.

7. Vogler R.E., Beltramino A.A., Sede M.M., Gutiérrez Gregoric D.E., Núñez V., Rumi A. The giant Africansnail, Achatina fulica (Gastropoda: Achatinidae): Using bioclimatic models to identify South American areas susceptible to invasion. American Malacological Bulletin, 2013. - .31(1): pp. 39-50.

8. Ogbu, C.C., Ani, A.O., Emeh, M., 2014. Feed preferences and feeding behaviour of two species of african giant land snails preferencias y comportamiento alimentario de dos especies de caracoles terrestres gigantes africanos // Recibido: 3-4-13. Aceptado: 17-3-14. Arch. Zootec. 63 (242): pp. 337-347.

9. Hayes, K.A., Joshi, R.C., Thiengo, S.C., Cowie, R.H., 2008. Out of South America: multiple origins of non-native apple snails in Asia. Diversity Distrib., 14 (4): pp. 701-712.

10. Анализ рынка съедобных лягушек и улиток Украиныл. 2018 год. Компания Pro-Consulting, 2018. - 44 c.

11. Улиточная ферма - быстрая прибыль! [Електронний ресурс]. Точка доступy: https://zdravlyk.prom.ua/a328292-ulitochnaya-fermabystraya.html.

12. Винничук Ю. Что известно об экспорте улиток из Украинь. [Електронний ресурс]. Точка доступу: https://biz.censor.net.ua/resonance/3019292/chto izvestno ob eksporte ulitok iz ukrainy.

13. "Своя ніша": чому україниі розводять равликів, хоча не можуть їх продатии. Електронний ресурс. [Точка доступу]: httрs://agroonline.com.ua/uk/public/blog/40235/details.

14. Як равлики сало обігнали // Україна молода, 2017. Випуск № 125.919 Жовтня. http://www.umoloda.kiev.ua/number/3226/159/116867.

15. Xiangqian X., Chen C., Yeast A. Alternative protein resources in China. [Електронний ресурс]. Tочка доступу: https://www.allaboutfeed.net/New-Proteins/Articles/2018/10/Alternative-protein-resources-in-China-345433E.

16. Halwart, M., 2006. Fish as biological control agents of golden apple snails in Philippine rice fields. In: Joshi, R. C.; Sebastian, L. S. (Eds.), Global advances in ecology and management of golden apple snails: pp. 363-374.

17. Joshi, R.C., Cowie, R.H., Sebastian, L.S., 2017. Biology and management of invasive apple snails. Philippine Rice Res. Institute (PhilRice), Maligaya, Science City of Muñoz, Nueva Ecija. P. 3119.

18. Phonekhampheng, O., Hung, L.T., Lindberg, J.E., 2009. Ensiling of Golden Apple snails (Pomacea canaliculata) and growth performance of African catfish (Clarias gariepinus) fingerlings fed diets with raw and ensiled Golden Apple snails as protein source. Livest. Res. Rural Dev., p. 21 (2).

19. Etchu K., et al. "Comparative performance of three edible snail species using intensive cage housing system in Cameroon”. Bulletin of Animal Health and Production in Africa 56.4 (2008): pp. 345-352.

20. Неквапливі підопічні, які дають швидкий прибуток: про створення в Украӥні ферми равликів. [Електронний ресурс]. Точка docmyny: $\quad$ https://pro-consulting.ua/ua/pressroom/netoroplivye-podopechnye-prinosyashie-bystruyu-pribyl-o-sozdanii-v-ukraineulitochnoj-fermy.

21. Mogbo T.C., et al. "Growth performance of snails (Achatina fulucia) fed with three different feed materials". American Journal of Biology and Life Sciences 2.4 (2014): pp.96-99.

22. Nyameasem J.K., Borketey-La E.B. Effect of formulated diets on growth and reproductive performance of the west african giant snail (Achatina achatina) // ARPN Journal of Agricultural and Biological Science. VOL. 9, NO. 1, JANUARY 2014. pp. 1-6.

23. Okon B., Ibom L.A., Ettah H.E., Ukpuho I.E. Effects of genotype, dietary protein and energy on the reproductive and growth traits of parents and 11 hatchlings of Achatina achatina (L) snails in Nigeria // International Journal of Applied Science and Technology Vol. 2 No. 1; January 2012. - pp. 179-185.

24. Egonmwan, R., 2007. Recent Advances in the Biology of Giant African Land Snails (On-line pdf). Federal University of Agriculture, Abeokuta. Accessed March 05, P. 201.

25. Mayaki O.M.,Ozumba A.U., Aderele A.A., DaramolaA.O. Effect of Sources of Fibre on Performance of Growing Snail // Nigerian Food Journal. Volume 31, Issue 1, 2013, pp. 28-32.

26. Бурлака В.А., Шевчук В.Ф., Беляєв С.М. Виромування слимака роду Неlix ротатіа в умовах Полісся Украӥни// Екологофункціональні та фауністичні аспекти досліджень молюсків, їх роль у біоіндикапї стану навколишнього середовища Збірн.наук.пр. Житомир «Волинь» . - 2004. - C. 15-17.

27. Freeman E.T. "Farmer Level Technical-note, improved snail farming" (2013): P. 27.

28. Owoseni D.O., Adetunji A.A. "The effect of feeds on weight of African giant snails (Archachatina marginata)". World Journal of Animal Science Research 1.1 (2013): pp. 1-7.

29. Ani A.O., et al. "Growth performances of African giant land snail (Achatina achatina) fed varying dietary protein and energy levels". ARPN Journal of Agriculture and Biological Science 8.2 (2013): pp. 184-190.

30. Ахатинка - универсальная белково-кальииевая подкормка для улиток. [Електронний ресурс]. Точка доступу: https://faunamarket.com/products/7661.

31. Корм для Ахатин зерно-кальиесмесь сухопутных улиток 100 г Zеlena Zоо. [Електронний ресурс]. Точка доступу: http://aquamaniya.com.ua/zootovar/terrarium/korm-zerno-kaltsesmes-dlya-ulitok-ahatin.

32. Amubode, F.O ; Ogogo, A U., 1995. Performance of snails (Archachatina marginata) fed varying levels of calorie-protein supplementary diets. Nigerian J. Forestry, 24/25: pp. 36-43.

33. Равликова ферма в селі Копачинці. [Електронний ресурс]. Точка доступу: https://www.ravlyk.if.ua.

34. Гордеева Е.А., Логинова М.Н. Наблюдение за ростом и развитием сухопутныхх улиток ахатин (Асhаtina sp.) // Юный ученый. 2016. - №3. - C. 165-170.

Надійшла 19.11.2018. До друку 28.11.2018. Рецензія 26.11.18 